\title{
Fifty years of impact on liver pathology: a history of the Gnomes
}

\author{
Michael Torbenson ${ }^{1} \cdot$ Valeer Desmet $^{2} \cdot$ Helmut Denk $^{3} \cdot$ Francesco Callea $^{4} \cdot$ Alastair D. Burt $^{5,6} \cdot$ Stefan G. Hübscher ${ }^{7,8}$. \\ Luigi Terracciano $^{9} \cdot$ Hans-Peter Dienes ${ }^{10} \cdot$ Zachary D. Goodman $^{11} \cdot$ Pierre Bedossa $^{5,12} \cdot$ Ian R. Wanless ${ }^{13}$. \\ Eve A. Roberts ${ }^{14}$. Elizabeth M. Brunt ${ }^{15}$. Andrew D. Clouston ${ }^{16}$. Annette S.H. Gouw ${ }^{17}$ - David Kleiner ${ }^{18}$. \\ Peter Schirmacher ${ }^{19} \cdot$ Dina Tiniakos ${ }^{5,20}$ (D)
}

Received: 24 April 2020 / Revised: 14 June 2020 / Accepted: 17 June 2020 / Published online: 30 June 2020

(C) The Author(s) 2020

\begin{abstract}
Professional societies play a major role in medicine and science. The societies tend to be large with well-developed administrative structures. An additional model, however, is based on small groups of experts who meet regularly in an egalitarian model in order to discuss disease-specific scientific and medical problems. In order to illustrate the effectiveness of this model, the history and practices are examined of a long-standing successful example, the International Liver Pathology Group, better known as the Gnomes. The history shows that groups such as the Gnomes offer a number of important benefits not available in larger societies and nurturing such groups advances science and medicine in meaningful ways. The success of the Gnomes' approach provides a road map for future small scientific groups.
\end{abstract}

Keywords Liver $\cdot$ Pathology $\cdot$ Scientific group $\cdot$ Model $\cdot$ History

\section{Introduction}

Professional societies play a major role in shaping concepts, prioritizing academic pursuits, and providing expert guidance for clinical management challenges in patient care. Professional societies in most settings tend to be large in order to maximize impact. They have permanent bureaucratic structures to help them operate consistently and effectively, including official bylaws and standard operating procedures that outline committee structure and committee interactions, with a President and Executive Committee, and frequently a professional manager overseeing the entire operation.

An additional model, however, is based on small groups of experts who meet regularly in an egalitarian model without formal structure in order to discuss disease-specific scientific and medical problems. Of course, this model is not intended to replace or compete with the roles of traditional professional societies, but this model is nimble and flexible and can have a

Electronic supplementary material The online version of this article (https://doi.org/10.1007/s00428-020-02879-5) contains supplementary material, which is available to authorized users.

Dina Tiniakos

Dina.Tiniakos@newcastle.ac.uk

Extended author information available on the last page of the article great impact on medicine and science. In order to illustrate this model, the history of a notable example is studied: the International Liver Pathology Group that in 2018 celebrated its 50th anniversary.

\section{Origin and development of the Gnomes}

The International Liver Pathology Group, better known as the Gnomes, emerged spontaneously in 1967 when a group of expert hepatologists and liver pathologists met to take on one of the most pressing problems of the day - how should chronic hepatitis be conceptualized, and what terms should be used to capture the various injury patterns seen on liver biopsy? This problem emerged because of the rapid spread during the 1950s and 1960s of the then new technique of using needle biopsies for the diagnosis and management of patients with liver disease. It was clear to pathologists and hepatologists that there were different patterns of hepatic injury, but the different patterns and their significance were confusing, at one point leading to at least 40 different terms in use for chronic hepatitis in the medical literature [1].

This issue was tackled in 1966 by the leadership of the newly formed European Association for the Study of the Liver (EASL) at the first annual meeting in Marburg, 
Germany. The EASL President, Gustav-Adolf Martini, and the Secretary, Jan De Groote (hepatologist and one of the founding members of the Gnomes from Leuven, Belgium), recognized the need for consensus on terminology for hepatitis injury patterns, so that uniform terminology would be used in the literature and permit fuller and more rapid progress in understanding inflammation of the liver [2]. To address this issue, it was decided to organize a session on this topic for the 2nd annual meeting of EASL, which was to be held in Gothenburg, Sweden, in 1967. Two German pathologists, Peter Gedigk from Bonn and Gerhard Korb from Weiden, were asked to host a slide seminar on this topic; both became founding members of the Gnomes [2]. Hans Popper, an Austrian-born liver pathologist working in New York, USA, had also been invited, but was unable to attend [2]. The session was attended by at least fifty individuals interested in hepatitis. The session was intense, stimulating, and so rewarding that at the suggestion of Jan De Groote a dozen attendees decided to skip the rest of the EASL meeting and continue their discussion on the terminology of hepatitis [3, 4]. They realized they would need more time than this single meeting afforded, so they decided to take their preliminary consensus classification of hepatitis terminology and apply it to a group of circulated slides, and then to meet again. This next meeting, which took place on July 3-5, 1968, at the University of Zürich, Switzerland, is generally considered to be the first meeting and the official birth of the Gnomes, though at this point the group was known as the "European Liver Pathology Group" and had not acquired the moniker of Gnomes.

The Zürich meeting was hosted by Martin Schmid, another founding member of the Gnomes, and was sponsored in part by Hoffman-La Roche \& Company [5]. The paper that resulted from the Zürich meeting is titled "A classification of chronic hepatitis" and summarized the new consensus classification of hepatitis developed by the nascent group soon to become known as the Gnomes. At the end of each day of this first meeting, Peter Scheuer (one of the founding members) typed up a summary of the day's discussion on a borrowed typewriter. As the only fluent English speaker, he became the de facto scribe and the meeting summaries formed the basis for the group's first paper [5]. The paper was quickly published in The Lancet in the fall of 1968 . The classification system proposed in the paper attempted to identify patterns of hepatitis that were more likely to progress to cirrhosis (chronic aggressive hepatitis) versus those that were thought to be more indolent (chronic persistent hepatitis). This classification system built upon the earlier work of Valeer Desmet [3], which in turn was built on the 1966 publication of Martin Schmid [6], was an important early step in understanding chronic hepatitis and helped lay the foundation for modern understandings of inflammatory liver diseases. The basic dichotomy of chronic aggressive hepatitis versus chronic persistent hepatitis is no longer in use, but the core notion of the importance of "piecemeal necrosis" (now called interface activity) remains relevant to this day.

Following the Zürich meeting, this consensus paper was presented at the 1968 World Congress of Gastroenterology in Prague and subsequently at Karlovy Vary, Czech Republic, for the 1968 meeting of the International Association for the Study of the Liver (IASL) [3, 4]. The president of IASL, Dame Sheila Sherlock, listened with interest but commented later at the meeting banquet, with some disapproval, that the authors were like the "Gnomes of Zürich," exercising undue influence on the field of liver disease and on the histological terminology of hepatitis [4].

The term Gnomes of Zürich referred to a popular notion that a small secretive group of elect bankers in Zürich had an undue influence on the world's financial systems. When the term Gnomes was first used by Sheila Sherlock, it was thus intended to be disparaging. The term, however, was gradually adopted by the group, with a bit of humor and as a badge of honor, being more convenient than the official name European Liver Pathology Group (1968-1978) or the more expansive name International Liver Pathology Group, which was adopted in 1979 when Kamal Ishak joined the group as the first non-European. In publications, the authorship byline was often listed simply as "International Group." While the more formal name International Liver Pathology Group is still occasionally used, by and large members refer to the group as the Gnomes. Other key events in the history of the Gnomes are listed in Table 1.

\section{Members}

There were nine founding members of the Gnomes (Table 2). Three of the founding members (De Groote, Thaler, and Schmid) were hepatologists and the rest were pathologists [5]. The group was expanded over the next several years to 11 members and (Fig. 1) held steady at between 11 and 14 members (Fig. 2). This number was felt to be optimal, providing enough members to capture a wide breadth of expertise, but numbers that could still easily meet in a modest-sized room and allow all members to speak freely and informally [8]. New members are inducted when members are no longer able to circulate slides [2] because of retirement, health considerations, scheduling issues, etc. These "emeriti" Gnomes are always welcome to continue attending the meeting and otherwise fully participate.

To date, there have been 36 Gnomes. All members were European until Kamal Ishak was inducted into membership in 1979 (Table 2). Technically, Hans Popper had joined in 1970 as an American, but he was considered to be European, and not American, by the members of the Gnomes [4]. The first Canadian joined in 1986 (James Phillips) and the first Australian in 2008 (Andrew Clouston). The first woman 
Table 1 Key events in Gnomes' history

\begin{tabular}{|c|c|}
\hline Date & Key event \\
\hline 1967 & Spark that led to the creation of the Gnomes: EASL meeting in Gothenburg, Sweden \\
\hline \multirow[t]{3}{*}{1968} & First formal meeting of Gnomes: Zürich, Switzerland, July 3-5 \\
\hline & $\begin{array}{l}\text { First paper written by Gnomes; drafted at the end of the first meeting by Peter Scheuer; } \\
\text { published a few months later (September 1968) in Lancet }\end{array}$ \\
\hline & $\begin{array}{l}\text { The first paper's classification of hepatitis is presented at the IASL. This leads the IASL } \\
\text { president, Dame Sheila Sherlock, to complain the group is acting like the Gnomes } \\
\text { of Zürich, who were considered to have undue influence on financial markets }\end{array}$ \\
\hline \multirow[t]{2}{*}{1968} & First new member added to the group (Leonardo Bianchi, Basel, Switzerland) \\
\hline & Formal name for the group is "European Liver Pathology Group" [4] \\
\hline 1976 & First woman Gnome: Amelia Baptista \\
\hline 1979 & $\begin{array}{l}\text { First non-European member added to the group (Kamal Ishak). Hans Popper had joined } \\
\text { in } 1970 \text { but was largely considered by the group to be European [4] }\end{array}$ \\
\hline \multirow[t]{2}{*}{1983} & First meeting held outside of Europe/UK; held in Washington, DC, hosted by Kamal Ishak \\
\hline & Formal name is changed to "International Liver Pathology Group" [4] \\
\hline 1989 & $\begin{array}{l}\text { London meeting inspires Dr Amar Paul Dhillon, a liver pathologist working with Peter } \\
\text { Scheuer at the Royal Free Hospital, and two visiting pathologists, Drs Neil Theise } \\
\text { and Romano Colombari, to begin a similar group of liver devotees, called the Elves [7] }\end{array}$ \\
\hline 1990 & $\begin{array}{l}\text { The official red Gnomes hat was created by the mother of a medical student who was working } \\
\text { with Peter Scheuer at the time }[2,7] \text {. The student persuaded his mother to make a } \\
\text { hat suitable for a master gnome }\end{array}$ \\
\hline 2012 & $\begin{array}{l}\text { First meeting and Liver Symposium in Africa, held in Mwanza, Tanzania, hosted by } \\
\text { Francesco Callea }\end{array}$ \\
\hline 2013 & First meeting in Australia, held in Noosa, hosted by Andrew Clouston \\
\hline 2018 & 50th anniversary meeting held in Athens, Greece, hosted by Dina Tiniakos \\
\hline
\end{tabular}

Gnome was Amelia Baptista from Lisbon, Portugal, who joined the Gnomes in 1976 (Fig. 1).

When new members are needed, names of candidates are proposed by any active member and discussed by the entire group, with a final decision put to a vote. Criteria for membership are equally weighted towards scientific interest, diagnostic or clinical expertise, collegiality, and friendship [4]. Nonetheless, all candidates are anticipated to be academic leaders in the field of liver disease/liver pathology. For example, the 14 members attending the 2018 meeting in Athens, Greece - the 50th year anniversary meeting (Fig. 2) - had an average $h$-index of 54 (range 27-77). At the time of the 2018 meeting, their individual publications had been referenced in the peer-reviewed literature a total of 202, 550 times, with an average of 14, 468 citations per member (data from World Wide Web of Science, accessed February 4, 2018). In addition, at the time of the 50th year anniversary meeting, they were editors or sole authors on thirteen books on liver pathology, including the seminal MacSween's Pathology of the Liver and the volume on Liver Tumors published by the AFIP [9-21]. Finally, current Gnomes members have been or are President or Executive Officers in all of the major International, European, US, Canadian, and Australian professional societies dedicated to pathology and liver pathology, as well as broader liver-focused groups such as the Canadian
Association for the Study of the Liver (CASL) and the Austrian Academy of Sciences.

Over the years, the Gnomes have become aware of the critical shortage of pathologists in developing countries. The 2012 meeting, hosted by Franesco Callea, was held in Tanzania to support his ongoing efforts to provide pathology training at the Catholic University of Health and Allied Sciences - Bugando, Mwanza [22].

\section{Gnomes' modus operandi}

The group originally considered becoming a subcommittee of the EASL, but the members felt there were significant benefits to remaining an independent organization [4]. The group also decided to adopt an egalitarian structure, with no president, no secretary, and no bylaws [4]. Nonetheless, general customs and norms developed over the years for running the meetings (Supplementary material - Appendix). The meeting locations are chosen by the host, often being in the city of the host's hospital or academic department, and also at nearby resorts. The topics have varied, with most topics focused on medical liver diseases (Table 3). The topics have been wide ranging, covering almost all aspects of medical and tumor liver pathology. 
Table 2 Gnomes members listed by first year of membership, and city and country of origin. Members who joined the same year are listed in alphabetical order

\begin{tabular}{|c|c|c|c|}
\hline & Year & Member & City, country \\
\hline 1 & 1967 & Jan De Groote, founding member & Leuven, Belgium \\
\hline 2 & 1967 & Valeer Desmet, founding member & Leuven, Belgium \\
\hline 3 & 1967 & Peter Gedigk, founding member & Bonn, Germany \\
\hline 4 & 1967 & Gerhard Korb, founding member & Weiden, Germany \\
\hline 5 & 1967 & Hemming Poulsen, founding member & Copenhagen, Denmark \\
\hline 6 & 1967 & Peter Scheuer, founding member & London, UK \\
\hline 7 & 1967 & Martin Schmid, founding member & Zürich, Switzerland \\
\hline 8 & 1967 & Heribert Thaler, founding member & Vienna, Austria \\
\hline 9 & 1967 & Wilhelm Wepler, founding member & Kassel, Germany \\
\hline 10 & 1968 & Leonardo Bianchi & Basel, Switzerland \\
\hline 11 & $1969 / 70$ & Hans Popper & New York, NY, USA \\
\hline 12 & 1976 & Amelia Baptista & Lisbon, Portugal \\
\hline 13 & 1977 & Roderick MacSween & Glasgow, UK \\
\hline 14 & 1979 & Kamal Ishak & Washington, DC, USA \\
\hline 15 & 1986 & M. James Phillips & Toronto, Canada \\
\hline 16 & 1987 & Helmut Denk & Graz, Austria \\
\hline 17 & 1987 & Fred Gudat & Basel, Switzerland \\
\hline 18 & 1992 & Francesco Callea & Rome, Italy \\
\hline 19 & 1992 & Bernard Portmann & London, UK \\
\hline 20 & 1995 & Alastair Burt & Newcastle upon Tyne, UK \\
\hline 21 & 1995 & Stefan Hübscher & Birmingham, UK \\
\hline 22 & 1996 & Tania Roskams & Leuven, Belgium \\
\hline 23 & 1998 & Luigi Terracciano & Basel, Switzerland \\
\hline 24 & 2002 & Hans-Peter Dienes & Cologne, Germany \\
\hline 25 & 2002 & Jean-Yves Scoazec & Lyon, France \\
\hline 26 & 2003 & Pierre Bedossa & Paris, France \\
\hline 27 & 2003 & Zachary Goodman & Washington, DC, USA \\
\hline 28 & 2004 & Elizabeth Brunt & St. Louis, MO, USA \\
\hline 29 & 2004 & Eve Roberts & Toronto, Canada \\
\hline 30 & 2004 & Ian Wanless & Toronto, Canada \\
\hline 31 & 2008 & Andrew Clouston & Brisbane, Australia \\
\hline 32 & 2010 & Dina Tiniakos & Athens, Greece \\
\hline 33 & 2011 & Annette Gouw & Groningen, The Netherlands \\
\hline 34 & 2011 & Michael Torbenson & Baltimore, MD, USA \\
\hline 35 & 2018 & David Kleiner & Washington, DC, USA \\
\hline 36 & 2018 & Peter Schirmacher & Heidelberg, Germany \\
\hline
\end{tabular}

\section{Gnomes' scholarly contributions}

One of the key missions of the Gnomes is to publish position/ nomenclature/review articles to help advance the scientific understanding of liver disease [2]. To this end, there has been a regular production of Gnomes' papers, totaling 12 at the time of the 50th year anniversary meeting in 2018 (Table 4). These papers have been widely cited, with the two most highly cited papers focusing on classification of hepatitis. The first Gnomes" paper "A classification of chronic hepatitis" [5] has been cited 1016 times, while the most highly cited paper was published in 1995 and has 4747 citations: "Histological grading and staging of chronic hepatitis" [29].

\section{Organizational structures that contribute to success}

Fifty years is a long time for a small group to survive, let alone thrive - why has the Gnomes been successful and lasted so long? Peter Scheuer emphasized the deep satisfaction of sharing cases with other skilled pathologists, scientists, and 
Fig. 1 Leuven 1976 meetinghosts: Jan De Groote and Valeer Desmet. Park of the University Hospital Pellenberg. Left to right: Gnomes Poulsen, Popper,

Bianchi, De Groote, Baptista (new member), Scheuer, Gedigk, Schmid, Thaler, Korb, and Desmet

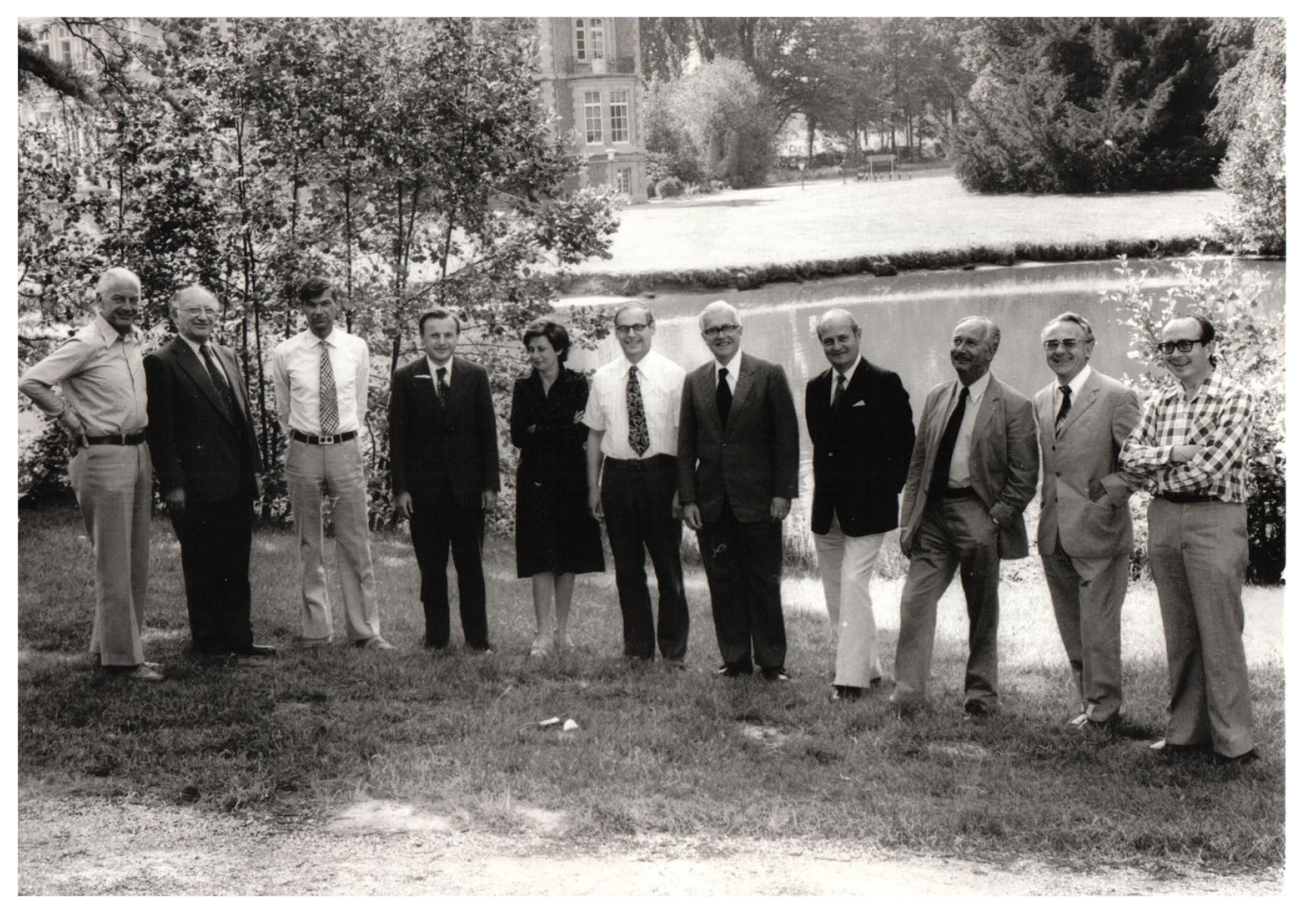

clinicians who share a passion for liver disease [2], as did Valeer Desmet [4]. Professors Scheuer, Desmet, and Bianchi all highlighted the importance of openly sharing ideas, questions, and knowledge without fear of embarrassment $[4,7,8]$. In fact, Leonardo Bianchi explicitly noted that the egalitarian organization does not tolerate hierarchy in determining primacy of ideas during discussions [8] or in determining group direction (Figs. 1 and 2).
The notion of group fit comes through as a key element important to the health of the Gnomes [2, 4]. This makes sense because the social and intellectual fabric of small groups like the Gnomes can be easily torn if a member is disrespectful, does not fully participate, or is otherwise unable to integrate into the group.

A third key element noted by Valeer Desmet is the ability to organize the group's efforts on a regular basis into meaningful
Fig. 2 Athens 2018 50th

anniversary meeting - host Dina Tiniakos. Back row, left to right: Hans Dienes, Zack Goodman, Pierre Bedossa, Eve Roberts, Mike Torbenson, Ian Wanless, Alastair Burt, Luigi Terracciano, Andrew Clouston, Jim McGown (Gnome mate), Dimitrios

Dougenis (Gnome mate). Front row, left to right: Yvonne Bury (observer), Ton Groothuis (Gnome mate), Jamie Goodman (Gnome mate), Annette Gouw, Heidi Dienes (Gnome mate), David Kleiner (new member), Dina Tiniakos, Peter Schirmacher (new member), Vanessa Torbenson (Gnome mate), Stefan Hübscher, and Francesco Callea (Elisabeth Brunt not in attendance)

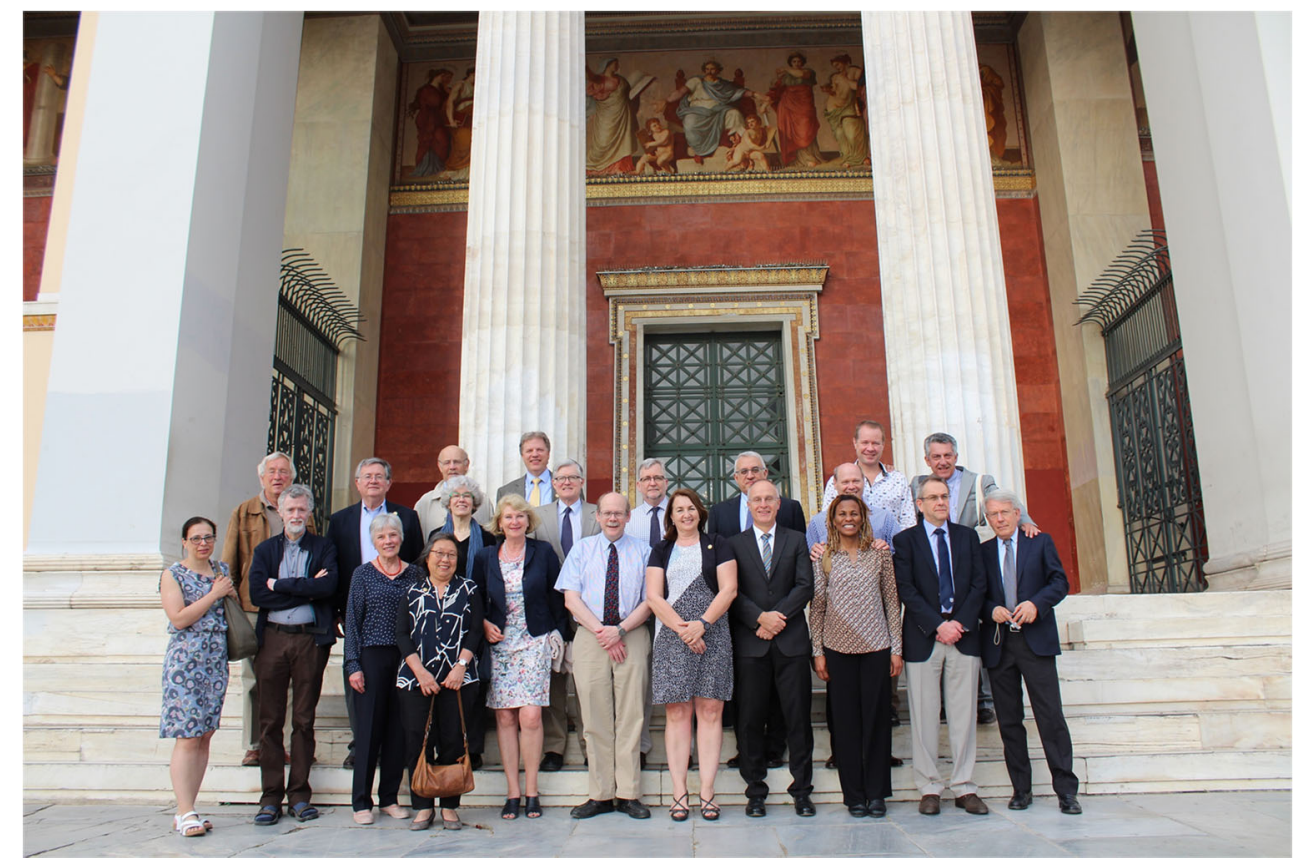


Table 3 Calendar of Gnomes' meetings

\begin{tabular}{|c|c|c|c|}
\hline Year & Meeting Location & Host & Topic \\
\hline 1967 & Gothenburg Sweden & EASL & Classification of chronic hepatitis \\
\hline 1968 & Zürich, Switzerland & Martin Schmid & Classification of chronic hepatitis \\
\hline 1969 & Leuven, Belgium & $\begin{array}{l}\text { Jan De Groote } \\
\text { Valeer Desmet }\end{array}$ & Acute versus chronic hepatitis markers of chronicity \\
\hline 1970 & Copenhagen, Denmark & Hemming Poulsen & Evolution of acute to chronic hepatitis \\
\hline 1971 & London, UK & Peter Scheuer & Drug-induced and toxic liver damage \\
\hline 1972 & Kassel, Germany & Wilhelm Wepler & Cholestatic versus hepatic liver disease \\
\hline 1973 & $\begin{array}{l}\text { Macerata, Italy } \\
\text { Invitation of Prof. Giorgio Menghini }\end{array}$ & Gerhard Korb & Drug-induced hepatitis and cholestasis \\
\hline 1974 & Basel, Switzerland & Leonardo Bianchi & $\begin{array}{l}\text { Outcomes of forms of chronic hepatitis (chronic persistent } \\
\text { and aggressive hepatitis) }\end{array}$ \\
\hline 1975 & Bonn, Germany & Peter Gedigk & $\begin{array}{l}\text { Aspects of severity of chronic hepatitis: confluent (bridging) } \\
\text { necrosis and its evolution }\end{array}$ \\
\hline 1976 & Leuven, Belgium & $\begin{array}{l}\text { Jan De Groote } \\
\text { Valeer Desmet }\end{array}$ & $\begin{array}{l}\text { Definition and importance of confluent necrosis and } \\
\text { of piecemeal necrosis }\end{array}$ \\
\hline 1977 & Vienna, Austria & Heribert Thaler & Alcoholic liver disease \\
\hline 1978 & Zürich, Switzerland & Martin Schmid & $\begin{array}{l}\text { Forms of alcoholic liver disease (cholestatic; rapidly evolving, etc.) } \\
\text { and types of cells (foamy, Mallory bodies, etc.) }\end{array}$ \\
\hline 1979 & London, UK & Peter Scheuer & Bile duct lesions \\
\hline 1980 & Weiden, Germany & Gerhard Korb & Etiology of cholestasis and bile duct lesions \\
\hline 1981 & Lisboa, Portugal & Amelia Baptista & Cholestatic syndromes \\
\hline 1982 & Glasgow, UK & Roderick MacSween & Aspects of non-A-non-B chronic hepatitis \\
\hline 1983 & Washington, DC, USA & Kamal Ishak & Aspects of hepatitis (including non-A-non-B) \\
\hline 1984 & Meisterschwanden, Switzerland & Leonardo Bianchi & Types and patterns of liver necrosis \\
\hline 1985 & Copenhagen, Denmark & Hemming Poulsen & Variants of piecemeal necrosis \\
\hline 1986 & Leuven (Pellenberg), Belgium & $\begin{array}{l}\text { Jan De Groote } \\
\text { Valeer Desmet }\end{array}$ & Metabolic liver disease \\
\hline 1987 & Saiger Höh (Titisee), Germany & Heribert Thaler & Metabolic liver disease \\
\hline 1988 & Ittingen, Switzerland (in historic Kartause) & Martin Schmid & Hepatocellular carcinoma \\
\hline 1989 & London, UK & Peter Scheuer & Hepatic epithelial tumors \\
\hline 1990 & Weiden, Germany & Gerhard Korb & Liver in systemic disease: granulomas \\
\hline 1991 & Graz, Austria & Helmut Denk & Hepatic granulomas \\
\hline 1992 & Sesimbra, Portugal & Amelia Baptista & $\begin{array}{l}\text { Liver pathology in transplantation } \\
\text { (of the liver, kidney, bone marrow) }\end{array}$ \\
\hline 1993 & Toronto, Canada & M. James Phillips & Transplantation pathology \\
\hline 1994 & Rheinfelden, Germany & $\begin{array}{l}\text { Fred Gudat } \\
\text { Leonardo Bianchi }\end{array}$ & $\begin{array}{l}\text { Grading and staging chronic hepatitis; primary sclerosing } \\
\text { cholangitis and differential diagnosis }\end{array}$ \\
\hline 1995 & Loch Lomond, UK & Roderick MacSween & Autoimmune cholangiopathies \\
\hline 1996 & Leuven, Belgium & $\begin{array}{l}\text { Valeer Desmet } \\
\text { Jan De Groote }\end{array}$ & Autoimmune cholangiopathies \\
\hline 1997 & Bethesda, USA & Kamal Ishak & Vascular diseases of the liver \\
\hline 1998 & Sirmione (Brescia), Italy & Francesco Callea & Vascular diseases of the liver \\
\hline 1999 & London, UK & Bernard Portmann & Lymphoproliferative diseases \\
\hline 2000 & Newcastle upon Tyne, UK & Alastair Burt & Liver and immunosuppression \\
\hline 2001 & Birmingham, UK & Stefan Hübscher & Hepatitis $\mathrm{C}$ infection in the immunocompromised host \\
\hline 2002 & Ravello, Italy & Luigi Terracciano & Ductular reaction \\
\hline 2003 & Leuven, Belgium & $\begin{array}{l}\text { Tania Roskams } \\
\text { Valeer Desmet }\end{array}$ & Ductular reaction \\
\hline 2004 & Graz, Austria & Helmut Denk & Fatty liver diseases \\
\hline 2005 & Rome, Italy & Francesco Callea & Fatty liver diseases \\
\hline 2006 & Washington, DC, USA & Zachary Goodman & Hepatic fibrosis \\
\hline 2007 & Lyon, France & Jean-Yves Scoazec & Hepatic fibrosis \\
\hline
\end{tabular}


Table 3 (continued)

\begin{tabular}{llll}
\hline Year & Meeting Location & Host & Topic \\
\hline 2008 & Cologne, Germany & Hans-Peter Dienes & Liver infections (excluding viral hepatitis) \\
2009 & Halifax, Canada & $\begin{array}{l}\text { Ian Wanless } \\
\text { Eve Roberts } \\
\text { Pierre Bedossa }\end{array}$ & Biliary mass lesions \\
2010 & Paris, France & Elizabeth Brunt & Cells of the sinusoid \\
2011 & St. Louis, USA & Francesco Callea & Pathology of sinusoids \\
2012 & Mwanza, Tanzania & Andrew Clouston & Well-differentiated hepatocellular lesions \\
2013 & Noosa, Australia & Luigi Terracciano & Well-differentiated hepatocellular lesions \\
2014 & Ravello, Italy & Stefan Hübscher & Acute hepatitis, including acute liver failure \\
2015 & Birmingham, UK & Alastair Burt & Patterns of acute liver injury \\
2016 & Adelaide, Australia & Annette Gouw & Non-tumor vascular liver disease \\
2017 & Groningen, The Netherlands & Dina Tiniakos & Drug-induced liver injury \\
2018 & Athens, Greece & &
\end{tabular}

contributions to the scientific literature [4]. All of the Gnomes are committed to academic endeavors, and it seems natural and entirely fitting that this aspect of Gnome membership would be highly valued.

Finally, the seamless integration of the Gnome partners and other family members into the social activities of the evenings and weekends brings to the Gnomes a true sense of community (Fig. 2).. Members get to know dimensions of each other not normally visible from typical academic meetings through shared social events, dinners, and other events. These informal environments promote trust, respect, and understanding.

\section{Central role of histomorphology}

Leonardo Bianchi emphasized the importance of pre-meeting circulated slides and pre-meeting submission of diagnoses as a key element of the Gnomes [8]. Based on a single
Table 4 Papers of the Gnomes: "International Liver Pathology Group"

\begin{tabular}{|c|c|c|c|c|}
\hline \multirow[t]{2}{*}{ Number } & \multirow[t]{2}{*}{ Year } & \multirow[t]{2}{*}{ Title } & \multirow{2}{*}{$\begin{array}{l}\text { Google } \\
\text { Scholar } \\
\text { Number of } \\
\text { citations* }\end{array}$} & \multirow{2}{*}{$\begin{array}{l}\text { Web of } \\
\text { Science } \\
\text { Number of } \\
\text { citations* }\end{array}$} \\
\hline & & & & \\
\hline 1 & 1968 & A classification of chronic hepatitis [5] & 1016 & NA \\
\hline 2 & 1971 & Morphological criteria in viral hepatitis [23] & 117 & NA \\
\hline 3 & 1974 & $\begin{array}{l}\text { Guidelines for diagnosis of therapeutic } \\
\text { drug induced liver injury in liver biopsies [24] }\end{array}$ & 45 & NA \\
\hline 4 & 1977 & Acute and chronic hepatitis revisited [7] & 334 & 82 \\
\hline 5 & 1981 & Alcoholic liver disease: morphological manifestations [25] & 123 & 68 \\
\hline 6 & 1983 & Histopathology of the intrahepatic biliary tree [26] & 24 & 17 \\
\hline 7 & 1988 & $\begin{array}{l}\text { The diagnostic significance of periportal hepatic necrosis and } \\
\text { inflammation [27] }\end{array}$ & 35 & 24 \\
\hline 8 & 1994 & $\begin{array}{l}\text { Guidelines for the diagnosis and interpretation of hepatic } \\
\text { granulomas [28] }\end{array}$ & 57 & 27 \\
\hline 9 & 1995 & Histological grading and staging of chronic hepatitis [29] & 4747 & 3393 \\
\hline 10 & 2003 & $\begin{array}{l}\text { Histopathology of portal hypertension: a practical guideline } \\
\text { [30] }\end{array}$ & 55 & 35 \\
\hline 11 & 2014 & Pathology of the liver sinusoids [31] & 39 & 23 \\
\hline 12 & 2014 & $\begin{array}{l}\text { Well differentiated hepatocellular neoplasms of uncertain } \\
\text { malignant potential: a proposal for a new diagnostic } \\
\text { category [26] }\end{array}$ & 37 & 28 \\
\hline Total & & Total & 6629 & \\
\hline
\end{tabular}

NA not available

*As of March 29, 2020. Google Scholar citations include peer-reviewed articles as well as book chapters and other scholarly publications. The Web of Science includes almost exclusively primary articles and review articles 
hematoxylin and eosin (H\&E) slide, one unstained slide, and limited history, Gnomes members are asked to provide a diagnosis and limited differential. This unique approach requires each Gnome to commit to a diagnosis beforehand, allowing unbiased assessment for areas of consensus and areas of disagreement.

In addition, the careful examination of the H\&E-stained slide at these meetings has led to the detection and interpretation of previously undescribed structural and cellular alterations. The Gnomes not only fully embrace modern approaches such as molecular pathology, but also understand the continued value of careful morphological studies. Examples of observations made at Gnomes meetings and subsequently described in follow-up studies include the strong association of calcification within alpha-1-antitrypsin globules with the Mmalton variant [25], the visualization of lipid droplets within eosinophilic inclusions of fibrinogen, corresponding to apo-beta-lipoproteins [32], and histological changes in fibrinogen storage disease of hypofibrinogenemia and hypo-apo-beta-lipoprotein [33].

The Gnomes' slide sets are also very important as tools for educational training, including places or countries where $\mathrm{H} \& \mathrm{E}$ is the only available stain. In the last few years, some of the Gnomes have submitted scanned digital slides instead of glass slides, which also serve as an important educational tool, though the relative advantages and shortcomings of their use are still being explored.

At the end of the meeting, there also are opportunities for members to present their personal ongoing research. The opportunity to fully and openly discuss early ideas and data has been important in the process of refining many new ideas. There is a well-respected honor code that allows presentation of these initial ideas and early study results, without concern for other members absconding with them. These scientific topics incorporate and extend classical morphology using experimental models, molecular techniques, and biochemical methods, in order to better understand the basic principles of the disease and its morphological patterns. As one example, early work on the keratin nature of Mallory-Denk bodies was presented by Helmut Denk to the Gnomes, leading to vigorous and fruitful discussion by the group.

\section{Other examples of the small group model}

The core elements of the Gnomes model have been replicated by another group of liver pathologists, founded in 1990 and called the Elves, assisted by Peter Scheuer, one of the founding Gnomes members. Their formal name "The International Liver Pathology Study Group" is easily confused with the formal name of the Gnomes (International Liver Pathology Group), so both groups generally use their more informal but distinctive names. The Elves have enjoyed great success and their history and accomplishments were recently reviewed [34].

\section{The future of the Gnomes}

The Gnomes have consistently contributed to liver pathology for 50 years, but the future depends on the efforts of current members to keep it relevant, healthy, and productive. This depends on wise choices when selecting new members and on a rigorous and vigorous pursuit of the fundamental goal of the Gnomes: to improve the understanding of liver disease by tackling important issues in patterns of liver disease and in terminology.

For the first 50 years, the Gnomes focused their efforts on the histomorphologic patterns of disease. These activities remain important but now have to be more fully interwoven with the advances in the treatments for liver disease and improvements in non-invasive methods for diagnosing liver disease, assessing disease activity, assessing fibrosis, and integrating molecular findings into patient care. Starting about 10 years ago, the changes in treatment of liver disease have been rapid and sometimes stunning, with hepatitis $\mathrm{C}$ being a good example, in which rapid changes in the treatment and in non-invasive methods of assessing fibrosis have eliminated most of the clinical need for liver biopsy. These improvements in patient care are celebrated by all, especially Gnomes members.

Antipathy towards the value of liver pathology, however, is spreading among some clinicians, who express doubts about its usefulness in diagnosing and managing liver disease. The reasons for this are complex, but in part include the reduced exposure and understanding of liver pathology by newly trained physicians, who often receive considerably less training on normal histology and histopathology during medical school than formerly. In addition, there is a natural revision of diagnostic and treatment algorithms as new technology improves patient care. Refining the best fit for invasive and non-invasive methods in patient care takes time. Nonetheless, in all areas in which liver pathology can improve patient care, the Gnomes are committed to vigorously advancing the science of liver pathology interpretation.

The Gnomes experience indicates that small, agile professional groups can play an important role in medicine. These, and others like it, offer a number of specific benefits not available in larger specialty societies. We believe that nurturing such groups advances science and medicine in important, meaningful ways. The documentation of the Gnomes approach can provide a road map for the formation of future groups with a specific scientific focus.

Author contributions MT, VD, and DGT drafted the manuscript. All authors made substantial contributions to the conception of the work, 
revised the manuscript critically for important intellectual content, and approved the version to be published.

\section{Compliance with ethical standards}

Conflict of interest The authors declare that they have no conflict of interest.

Open Access This article is licensed under a Creative Commons Attribution 4.0 International License, which permits use, sharing, adaptation, distribution and reproduction in any medium or format, as long as you give appropriate credit to the original author(s) and the source, provide a link to the Creative Commons licence, and indicate if changes were made. The images or other third party material in this article are included in the article's Creative Commons licence, unless indicated otherwise in a credit line to the material. If material is not included in the article's Creative Commons licence and your intended use is not permitted by statutory regulation or exceeds the permitted use, you will need to obtain permission directly from the copyright holder. To view a copy of this licence, visit http://creativecommons.org/licenses/by/4.0/.

\section{References}

1. Reuben A (2002) Where are the gnomes of yesteryear? Hepatology 35:1554-1557

2. Scheuer PJ (1999) The "Gnomes": an adventure in hepatopathology. Ann Diagn Pathol 3:134-139

3. Desmet VJ (2009) The amazing universe of hepatic microstructure. Hepatology 50:333-344

4. Desmet VJ (2010) The Gnomes - born of EASL. In: Williams R (ed) EASL past and present. EASL office, Geneva, pp 19-20

5. De Groote J, Desmet VJ, Gedigk P, Korb G et al (1968) A classification of chronic hepatitis. Lancet 2:626-628

6. Schmid M (1966) Die chronische Hepatitis. Springer Verlag, Berlin, p 158

7. Scheuer PJ (1997) What's in a Gnome? Br Med J 315:1668

8. Bianchi L (2004) Who are the Gnomes? In: Blum H, Maier K, Rodés J, Sauerbruch T (eds) Liver diseases: advances in treatment and prevention. Springer, Berlin, pp 50-51

9. Callea F, Zorzi M, Desmet V (1986) Associazione volontari italiani del sangue. Brescia Division. Viral hepatitis, vol viii. Springer Verlag, Berlin, p 110

10. Dienes HP (1989) Viral and autoimmune hepatitis: morphologic and pathogenetic aspects of cell damage in hepatitis with potential chronicity. Fischer, Stuttgart, p 107

11. Goodman Z, Hoofnagle JH (1991) Liver biopsy interpretation for the 90's clinicopathologic correlations in liver disease AASLD

12. Kelso A, Clouston A (1996) Cytokines in transplantation. RG Landes, Austin

13. Dienes HP, Schirmacher P, Brechot C, Okuda K (2000) Chronic hepatitis: new concepts of pathogenesis, diagnosis and treatment. Springer Verlag, Berlin

14. Ishak KG, Goodman Z, Stocker JT (2001) Tumors of the liver and intrahepatic bile ducts. American Registry of Pathology, Washinton

15. Dienes HP (2005) Autoimmune liver disease: proceedings of the Falk Symposium 142 held in Freiburg, Germany, October 12-13, 2004. Springer, Dordrecht Norwell

16. Levison D, Reid R, Burt AD, Harrison DJ et al (2008) Muir's textbook of pathology, 14th edn. CRC Press, London
17. Mounajjed T, Chandan VS, Torbenson MS (2015) Surgical pathology of liver tumors. Springer, Heidelberg

18. Torbenson MS (2015) Biopsy interpretation of the liver. Wolters Kluwer Health, Philadelphia

19. Burt AD, Ferrell LD, Hübscher S (2018) MacSween's pathology of the liver, 7th edn. Elsevier, Philadelphia

20. Torbenson MS, Zen Y, Yeh MM (2018) Tumors of the liver. P American Registry of Pathology, Washington

21. Torbenson MS, Zhang L, Moreira RK (2018) Surgical pathology of the liver. Wolters Kluwer Health, Philadelphia

22. Tumino R, Rambau PF, Callea F, Leoncini L, Monaco R, Kahima J, Stracca Pansa V, Viberti L, Amadori D, Giovenali P, Mteta KA (2017) The surgical pathology laboratory in Mwanza, Tanzania: a survey on the reproducibility of diagnoses after the first years of autonomous activity. Infect Agent Cancer 12:6

23. Bianchi L, De Groote J, Desmet V et al (1971) Morphological criteria in viral hepatitis. Review by an international group. Lancet 1:333-337

24. Bianchi L, De Groote J, Desmet V et al (1974) Guidelines for diagnosis of therapeutic drug-induced liver injury in liver biopsies. Lancet 1:854-857

25. Callea F, Giovannoni I, Francalanci P, Boldrini R, Faa G, Medicina D, Nobili V, Desmet VJ, Ishak K, Seyama K, Bellacchio E (2018) Mineralization of alpha-1-antitrypsin inclusion bodies in Mmalton alpha-1-antitrypsin deficiency. Orphanet J Rare Dis 13:79

26. Baptista A, Bianchi L, De Groote J et al (1983) Histopathology of the intrahepatic biliary tree. Liver 3:161-175

27. Baptista A, Bianchi L, De Groote J, Desmet VJ et al (1988) The diagnostic significance of periportal hepatic necrosis and inflammation. Histopathology 12:569-579

28. Denk H, Scheuer PJ, Baptista A, Bianchi L et al (1994) Guidelines for the diagnosis and interpretation of hepatic granulomas. Histopathology 25:209-218

29. Ishak K, Baptista A, Bianchi L, Callea F, de Groote J, Gudat F, Denk H, Desmet V, Korb G, MacSween RNM, Phillips MJ, Portmann BG, Poulsen H, Scheuer PJ, Schmid M, Thaler H (1995) Histological grading and staging of chronic hepatitis. J Hepatol 22:696-699

30. Roskams T, Baptista A, Bianchi L, Burt A, Callea F, Denk H, de Groote J, Desmet V, Hubscher S, Ishak K, MacSween R, Portmann B, Poulson H, Scheuer P, Terracciano L, Thaler H (2003) Histopathology of portal hypertension: a practical guideline. Histopathology 42:2-13

31. Brunt EM, Gouw AS, Hubscher SG, Tiniakos DG et al (2014) Pathology of the liver sinusoids. Histopathology 64:907-920

32. Callea F, Giovannoni I, Sari S, Guldal E, Dalgic B, Akyol G, Sogo T, al-Hussaini A, Maggiore G, Bartuli A, Boldrini R, Francalanci P, Bellacchio E (2017) Fibrinogen gamma chain mutations provoke fibrinogen and apolipoprotein b plasma deficiency and liver storage. Int J Mol Sci 18:2717

33. Callea F, Giovannoni I, Sari S, Aksu AU, Esendagly G, Dalgic B, Boldrini R, Akyol G, Francalanci P, Bellacchio E (2017) A novel fibrinogen gamma chain mutation (c.1096C >G; p.His340Asp), fibrinogen Ankara, causing hypofibrinogenaemia and hepatic storage. Pathology 49:534-537

34. International Liver Pathology Study Group (2016) Strategies for a successful anatomic pathology subspecialty workgroup: the 26year collaboration of "The Elves". Acad Pathol 3: 2374289516653766

Publisher's note Springer Nature remains neutral with regard to jurisdictional claims in published maps and institutional affiliations. 


\section{Affiliations}

Michael Torbenson ${ }^{1} \cdot$ Valeer Desmet $^{2} \cdot$ Helmut Denk $^{3} \cdot$ Francesco Callea $^{4} \cdot$ Alastair D. Burt $^{5,6} \cdot$ Stefan G. Hübscher ${ }^{7,8}$. Luigi Terracciano ${ }^{9} \cdot$ Hans-Peter Dienes ${ }^{10} \cdot$ Zachary D. Goodman $^{11} \cdot$ Pierre Bedossa $^{5,12} \cdot$ Ian R. Wanless ${ }^{13}$. Eve A. Roberts ${ }^{14}$ • Elizabeth M. Brunt ${ }^{15}$. Andrew D. Clouston ${ }^{16}$. Annette S.H. Gouw ${ }^{17}$ - David Kleiner ${ }^{18}$. Peter Schirmacher ${ }^{19}$. Dina Tiniakos ${ }^{5,20}$

1 Department of Laboratory Medicine and Pathology, Mayo Clinic, Rochester, MN, USA

2 Histology and Pathology, Faculty of Medicine, K.U. Leuven, Leuven, Belgium

3 Institute of Pathology, Medical University of Graz, Graz, Austria

4 Ospedale Pediatrico Bambino Gesu, 00165 Rome, Italy

5 Translational \& Clinical Research Institute, Faculty of Medical Sciences, Newcastle University, Framlington Place, Newcastle upon Tyne NE2 4HH, UK

6 Faculty of Health and Medical Sciences, University of Adelaide School of Medicine, Adelaide, South Australia 5005, Australia

7 Institute of Immunology and Immunotherapy, University of Birmingham, Birmingham, UK

8 Department of Cellular Pathology, Queen Elizabeth Hospital Birmingham, Birmingham B15 2WB, UK

9 Institute of Pathology, University of Basel, 4003 Basel, Switzerland

10 Institute of Pathology, Meduniwien, Medical University of Vienna, 1090 Wien, Austria
11 Center for Liver Diseases, Inova Fairfax Hospital, Falls Church, VA 22042, USA

12 LiverPat, Paris, France

13 Department of Pathology, Dalhousie University, Queen Elizabeth II Health Sciences Centre, Halifax, Nova Scotia B3H 1V8, Canada

14 Division of Gastroenterology, Hepatology and Nutrition, The Hospital for Sick Children, Toronto, Ontario M5G1X8, Canada

15 Department of Pathology and Immunology, Washington University School of Medicine, St. Louis, MO 63110, USA

16 Centre for Liver Disease Research, School of Medicine (Southern), University of Queensland, Princess Alexandra Hospital, Ipswich Rd, Woolloongabba 4109, Australia

17 Department of Pathology and Medical Biology, University Medical Center Groningen, 9700 RB Groningen, The Netherlands

18 National Institutes of Health, Bethesda, MD, USA

19 Heidelberg University, Im Neuenheimer Feld 224, 69120 Heidelberg, Germany

20 Department of Pathology, Aretaieion Hospital, Medical School, National \& Kapodistrian University of Athens, Athens, Greece 